Original Research Paper

\title{
Proposed Soil Quality Index for Rehabilitated Tropical Forest Sites in Malaysia
}

\author{
${ }^{1,5}$ Daljit Singh Karam, ${ }^{2}$ Arifin Abdu, ${ }^{3}$ Keeren Sundara Rajoo, \\ ${ }^{4,5}$ Farrah Melissa Muharam, ${ }^{2}$ Mohamad Roslan Mohamad Kasim and ${ }^{2}$ Hazandy Abdul Hamid

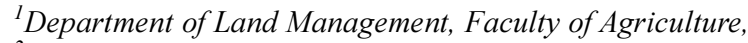 \\ ${ }^{2}$ Department of Forest Management, Faculty of Forestry, \\ ${ }^{3}$ Department of Biology, Faculty of Science, \\ ${ }^{4}$ Department of Agriculture Technology, Faculty of Agriculture, \\ ${ }^{5}$ Laboratory of Plantation Sciences and Technology, Institute of Plantation Studies, \\ Universiti Putra Malaysia, 43400 UPM Serdang, Selangor, Malaysia
}

Article history

Received: 11-05-2016

Revised: $29-12-2016$

Accepted: 30-12-2016

Corresponding Author:

Daljit Singh Karam

Department of Land

Management, Faculty of

Agriculture, Universiti Putra

Malaysia, 43400 UPM Serdang,

Selangor, Malaysia

Email: daljitkaramsingh@yahoo.com ; daljitsingh@upm.edu.my

\begin{abstract}
A proposed soil quality index named Tropical Soil Quality Index 2 (TSQI2) was developed in this study using statistical analysed data of selected properties (physical, chemical and biological) of composite soil samples collected from natural, secondary and rehabilitated forests of Chikus and Tapah Hill Forest Reserves, Perak, Malaysia. Results of soil evaluation using TSQI2 showed higher values for planted forest in Chikus Forest Reserve compared to those of the rehabilitated forest in Tapah Hill Forest Reserve. Likewise, rehabilitated forest of Tapah Hill Forest Reserve had slightly higher index value compared to that of the secondary forest. The higher index for rehabilitated Chikus Forest Reserve compared to that of the natural forest was due to high $\mathrm{MBC} / \mathrm{MBN}$ ratio values. The reason for this condition was the lower amount of microbial biomass nitrogen as compared to microbial biomass carbon. Plant growth performance of dominant trees species showed that Shorea leprosula was high in natural forests, followed by rehabilitated forest of Tapah Hill Forest Reserve. The newly proposed TSQI2 (which had been validated using actual data) is suitable for determining the quality of natural and rehabilitated forests in tropical regions.
\end{abstract}

Keywords: Rehabilitated Forest, Soil Properties, Tropical Soil Quality Index

\section{Introduction}

The demand for suitable soil indices in detecting and evaluating soil quality has increased over time (Anderson, 2003; Arifin et al., 2012). Soil quality indices can be defined as the indices developed from numbers of soil properties which could be the incorporation of more than one parameter which then used to evaluate and describe the quality of the studied soil area (Pang et al., 2006; Dawson et al., 2007). Soil quality is defined as the "capacity of the soil at a particular area or site to function within ecosystem boundaries and is able to sustain its biological productivity, environmental quality and enhance flora and fauna health" (Doran, 2002). Most of the soil quality indices focus on particular soil property or combination between physical and chemical properties, whereby biological parameters often left out and less appreciated.
Anderson (2003) summarized that there is a need for "microbial based-indicator" to be included in the formation of soil quality index because decomposition activities by microflora is crucial in sustaining the soil quality and productivity. Bastida et al. (2008) stated that microbial biomass is the most sensitive indicators compared to organic matter because it was found to be able to respond faster when subjected to environmental changes. Schloter et al. (2003) suggested that the development of soil quality indicator which incorporates soil microbiological and biochemical parameters should be able to work fairly well in all type of environments. However, there are still large debates by individual and bodies that work in the field of soil science about the accuracy and suitability of the application of the soil quality indices for soil quality assessment. This matter is believed to be influenced by the poor standardization of certain sampling and analysis procedures, differences of 
method used, heterogeneity of the soil, differences in climatic condition and vegetation distribution; last but not least, poor explanation of the soil quality index proposed (Bastida et al., 2008). Different approach in developing the soil quality indices could be due to different technique of implementation or sampling done. Table 1 shows some of the soil indices available in the literature. Soil index developed by Zornoza et al. (2007) is based on soil order properties analysed and proposed to be suitable to quantified soil quality in the same soil series. Puglisi et al. (2006) carried out in depth study of using phospholipid to measure soil quality status or changes. As for Amacher et al. (2007) Soil Quality Index, it was developed from vast sampling of soil at different forest areas in United States of America and the results are expressed based on score accumulation of permissible limits for each analysed property. Many other soil quality measurements used just particular soil properties like soil organic matter (Franzluebbers, 2002) or carbon sequestration. However, there are still arguments raise up due to diversity of soil on which particular index suit to measure the whole world soils.

Forest rehabilitation programs are established widely in tropical countries, including Malaysia. Most of the plantation management assume that the success of tree growth reflects the restoration of degraded forest land towards a healthier and higher fertility status without knowing that soil properties are the main indicators that show how well forest rehabilitation had successfully restored the condition of the planted forest to its original state like natural forest (Mohd-Aizat et al., 2014; Malik et al., 2015). Furthermore, most of the forest evaluation studies are carried out on temperate regions compared to tropical regions.
Biological properties including microbial enzymatic activity and biomass are sensitive indicator that illustrates the effect of changes or disturbances subjected on particular forest soil due to the sensitive nature and rapid turnover of the soil microorganisms (Karam et al., 2011; Arifin et al., 2012). In addition, availability of nutrients in the soils are also correlated and influenced by soil microorganisms which play a major role in nutrient cycling of the soil. Besides that, there is lack of information regarding suitable soil quality and fertility indices to determine the health between natural, secondary and rehabilitation forest. Furthermore, most of the soil quality indices are used to measure the fertility status of agricultural crops originating from land soils of temperate countries. Moreover, soil quality indices used for agricultural land like apple and vegetables orchards might not be suitable for forest soil quality assessment as agricultural plantation uses chemical fertilizer to fertilize the soil. In contrast, forest rehabilitation omits the use of any fertilizer to fertilize the soil except within the first two years of certain forest planting activities. A suitable soil quality index which incorporates selected physical, chemical and biological properties for evaluating the quality and fertility of forest rehabilitation especially for tropical forests in Malaysia was proposed and developed in this study. Through the new proposed tropical soil quality index, studies on the quality and health of forest and plantation in tropical areas will be easier and reliable because the index proposed is based on the current condition of natural forest which will be used as the benchmark to illustrate and differentiate the quality status of natural regeneration and rehabilitated forests.

Table 1. Selected soil indices for measuring soil quality in temperate regions

\begin{tabular}{lll}
\hline Soil index & Description & References \\
\hline (Inceptisol) $\mathrm{N}=0.448(\mathrm{P})$ & This index was developed from natural vegetation which & Zornoza et al. (2007) \\
+0.017 (water holding capacity) & has minimal human impacts. Total soil nitrogen, soil organic & \\
+0.410 (phosphatase) -0.567 (urease) & carbon and microbial biomass were used as & \\
+0.001 (microbial biomass $\mathrm{C}$ ) & predicted parameters &
\end{tabular}

+0.410 ( $\beta$-glucosidae)- 0.98

$($ Entisol) $\mathrm{SOC}=4.247(\mathrm{P})+8.183$

$(\beta$ - glucosidae) -7.949 (urease) +17.333

Soil Alteration Index (SAI)

Soil Quality Index (SQI)

This index was produced through canonical discriminant analysis of 15 phosphoilpid fatty acids using two data sets.

Based on analysis of forest from numerous

sites in Unites states of America. Index is presented

based on score accumulation

Each metabolic activity is dependent on the

availability of carbon sources. The study found that

both agricultural and forests soils shows similarity in

term of quantitative relationships between microbial biomass carbon and total carbon.

Soil organic matter
Based on the assumptions that soil organic carbon and nitrogen stratification with depth suitable to be used to predict the soil quality due to the fact that surface organic matter possessed the ability to control soil erosion, infiltration and nutrients conservation.
Puglisi et al. (2006)

Amacher et al. (2007)

Anderson (2003)

Franzluebbers (2002)

\section{西}




\section{Materials and Methods}

\section{Description of the Study Sites}

Rehabilitated forest $\left(\mathrm{N} 04.179394^{\circ} \mathrm{E} 101.31998^{\circ}, \pm 46\right.$ $\mathrm{m}$ above sea level) and secondary forest ( $\mathrm{N} 04.17336^{\circ} \mathrm{E}$ 101.31974, $\pm 32 \mathrm{~m}$ a.s.1.) at Tapah Hill Forest Reserve were selected. Planted forest was established in 1968 through enrichment planting technique by which new trees were planted in between the existing trees. As for secondary forest, the area was left idle without any forest treatment of rehabilitation done to allow it undergo natural regeneration. Shorea leprosula was found to be the most dominant species at both plots. Another two areas in Chikus Forest Reserve were selected which were natural forest $\left(\mathrm{N} 04.10076^{\circ} \mathrm{E} 101.19411^{\circ}, \pm 28 \mathrm{~m}\right.$ a.s.l) and 18year-old stand $S$. leprosula rehabilitated forest (N $04.09197^{\circ} \mathrm{E} 101.19499^{\circ}, \pm 28 \mathrm{~m}$ a.s.l.). The rehabilitated forest was subjected for multi-storied planting technique by which Acacia mangium was planted first to be the shade trees for Dipterocarpaceae species trees that is shade-tolerant. The planting distance from each tree in the planted forest was $10 \times 3 \mathrm{~m}$. The sampling was conducted in June to August 2010.

\section{Soil Sampling and Plant Growth}

Six subplots $(20 \times 20 \mathrm{~m})$ were established at each study plot. Composite soil samples were collected at 015 and 15-30 cm depths at each subplot. Soil samples for physical and chemical analyses were air-dried for $48 \mathrm{~h}$ and kept in clean polyethylene bags prior to analyses. Moist and fresh soil samples for biological properties studies was kept in UV-sterilized polyethylene bags and stored in $0-4^{\circ} \mathrm{C}$ chiller before been analysed in the laboratory. The dominating species in all plots which was $S$. leprosula diameter and height were selected for growth performances measurement.

\section{Soil Analyses}

Soil bulk density and porosity were determined by using disturbed soil sample technique as describe in Gupta (2007). Clay and sand were determined by using the universal pipette method (Gupta, 2007). Soil moisture content for each composite sample was determined using gravimetric method as used in Karam et al. (2012). Soil $\mathrm{pH}$ in water $\left(\mathrm{pH}_{\mathrm{w}}\right)$ was determined in 1:2.5 soil to distilled water ratio. Electrical conductivity was determined using 1:1 ratio of soil to distilled water and measured using EC meter. Carbon content was determined using dry combustion technique through carbon analyser while nitrogen content was determined using Kjedahl digestion method and the concentration of ammonium ions was measured using Auto-analyser (Ahmadpour et al., 2010; Abdu et al., 2011; Rajoo et al., 2013a; 2013b; 2016a; 2016b). Exchangeable bases (K+,
$\mathrm{Mg}^{2+}$ and $\mathrm{Ca}^{2+}$ ) were extracted using $1 \mathrm{M}$ ammonium acetate $\left(\mathrm{NH}_{4} \mathrm{OAc}\right)$ and then read using Atomic Absorption Spectrophotometer (AAS). Exchangeable aluminium was extracted using $1 \mathrm{M}$ potassium chloride $(\mathrm{KCl})$ solution and titrated using $0.01 \mathrm{M}$ hydrochloric acid ( $\mathrm{HCl})$ solution (Arifin et al., 2012; Karam et al., 2014). Bray and Kurtz II method extracting solution was used to extract the available phosphorus and the concentration was determined using Autoanalyser (Arifin et al., 2012). Microbial enzymatic activity was determined by using Fluorescein Diacetate (FDA) hydrolysis assay as described by and Gagnon et al. (2007) and Sánchez-Monedero et al. (2008). Microbial biomass carbon and nitrogen of the soil samples were extracting using rapid chloroform fumigation extraction approaches as described by Witt et al. (2000). Then, the concentration of microbial biomass carbon was determined using wet dichromate digestion oxidation (Vásquez-Murrieta et al., 2007; Karam et al., 2011; Singh et al., 2013; Karam et al., 2015). Microbial biomass nitrogen was determined using Kjedahl digestion and distillation technique (Brookes et al., 1985; Karam et al., 2013b).

\section{Statistical Analyses}

Principal Component Analysis (PCA) was used to develop the new index by using data analyses accumulated. Independent $t$-test was used to compare the error between actual and testing data in order to valid the new index. As for plant growth, one way Analysis of Variance (ANOVA) was implemented to compared the diameter and height increment between plots and Tukey's Test was selected for post-hoc test. Correlation analysis was carried out to determine significant differences between tree growth performance and proposed soil quality index.

\section{Results and Discussion}

Maintenance of soil quality is vital in order to ensure the sustainability of environment surround and the development of soil quality indicators can be a crucial indicator of land management at particular degraded forest or plantation areas (Herrick, 2000; Calster et al., 2007). Table 2 (selected results were extracted from Karam et al., 2012; 2013a) shows the results of soil analyses for each plot of Tapah Hill and Chikus Forest Reserves that was used in the development of the new index.

Earlier proposed index were shown below:

$$
\begin{aligned}
& {[(\text { Clay }+ \text { Sand }+ \text { Porosity }+ \text { Moisture }) / 100]} \\
& + \text { Bulk density }+\mathrm{pH}_{\mathrm{w}}+\mathrm{C} / \mathrm{N} \text { Ratio } \\
& +\mathrm{EC}+\text { Avail. } \mathrm{P}+\mathrm{CEC}+3\left(\mathrm{~K}^{+}+\mathrm{Mg}^{2+}+\mathrm{Ca}^{2+}-\mathrm{Al}^{3+}\right) \\
& +(\mathrm{MBC} / \mathrm{MBN} \text { Ratio })+\text { Enzymatic activity }
\end{aligned}
$$


Weighing factor was given for clay particles, sand particles, porosity and moisture content to smaller down the value by dividing these parameters results with 100 . In contrast, exchangeable bases and aluminium were given weighing factors of three due to low value of the respective parameters. After been subjected to PCA analyses results, the new index which named as Tropical Soil Quality Index 2 (TSQI2) derived was shown below:

Tropical Soil Quality Index 2

$=$ Bulk density $(1.829)+\mathrm{pH}_{\mathrm{w}}(1.086)$

$+\mathrm{EC}(1.332)+\mathrm{C} / \mathrm{N}$ Ratio $(0.693)+\mathrm{CEC}(1.009)$

+ Exch. $\mathrm{K}^{+}(1.104)+$ Avail. P (0.995) + MBC / MBN

Ratio (1.040) + Microbial enzymatic activity (1.027)
Proposed Tropical Soil Quality Index 2 consists of physical, chemical and biological properties parameters and show simpler index compared to the one which used for developing the new index in the beginning. Validation of the new index was carried out by comparing the differences of error between index of Equation 1 and 2 for actual and testing data. Testing data was obtained from the analyses data of $30 \%$. Table 3 shows the results of validation of the new index using Independent student $t$-test. Figure 1 shows the distribution of actual and testing data error. It shows that there are no significant differences between error of actual and testing data; hence, the newly developed TSQI2 was considered valid and suitable to be used for the measurement of tropical soil quality (Table 4).

Table 2. Selected soil physical, chemical and biological properties analysis for Tapah hill and Chikus forest reserves

\begin{tabular}{|c|c|c|c|c|c|c|c|c|}
\hline \multirow[b]{3}{*}{ Parameter } & \multicolumn{4}{|c|}{$0-15 \mathrm{~cm}$ depth } & \multicolumn{4}{|c|}{$15-30 \mathrm{~cm}$ depth } \\
\hline & \multicolumn{2}{|c|}{ Tapah hill forest } & \multicolumn{2}{|c|}{ Chikus forest } & \multicolumn{2}{|c|}{ Tapah hill forest } & \multicolumn{2}{|l|}{ Chikus forest } \\
\hline & $\mathrm{PF}(1)$ & SF & NF & $\mathrm{PF}(2)$ & $\mathrm{PF}(1)$ & $\mathrm{SF}$ & NF & $\mathrm{PF}(2)$ \\
\hline Bulk density $\left(\mathrm{g} \mathrm{cm}^{-3}\right)$ & $1.16(0.01)$ & $1.24(0.02)$ & $1.21(0.05)$ & $1.36(0.02)$ & $1.22(0.01)$ & $1.26(0.02)$ & $1.35(0.06)$ & $1.39(0.02)$ \\
\hline Porosity (\%) & $50.55(1.24)$ & $47.18(0.59)$ & $50.32(3.59)$ & $54.51(096)$ & $49.18(0.87)$ & $47.24(1.04)$ & $45.48(1.66)$ & $47.40(1.32)$ \\
\hline Clay $(\%)$ & $26.16(0.89)$ & $20.41(2.15)$ & $7.33(1.35)$ & $5.77(0.59)$ & $28.93(0.52)$ & $22.28(1.62)$ & $7.21(1.32)$ & $7.06(1.01)$ \\
\hline Sand $(\%)$ & $66.81(1.02)$ & $73.00(3.54)$ & $78.80(2.16)$ & $89.09(0.69)$ & $64.85(0.67)$ & $70.02(4.01)$ & $79.71(2.06)$ & $87.61(1.31)$ \\
\hline Moisture content $(\%)$ & $26.33(0.61)$ & $20.50(1.91)$ & $52.83(2.91)$ & 17.67(1.33) & $23.33(0.49)$ & $19.17(2.60)$ & $50.50(2.67)$ & $19.50(1.78)$ \\
\hline Soil acidity $(\mathrm{pH})$ & $4.36(0.11)$ & $4.19(0.05)$ & $4.16(0.08)$ & $4.22(0.03)$ & $4.42(0.10)$ & $4.23(0.08)$ & $4.65(0.10)$ & $4.40(0.02)$ \\
\hline $\mathrm{C} / \mathrm{N}$ ratio $\left(\mathrm{g} \mathrm{kg}^{-1}\right)$ & $1.55(0.11)$ & $1.47(0.16)$ & $2.01(0.23)$ & $2.36(0.51)$ & $1.42(0.12)$ & $1.63(0.35)$ & $1.83(0.13)$ & $1.97(0.13)$ \\
\hline $\mathrm{EC}\left(\mathrm{ds} \mathrm{m^{-1 } )}\right.$ & $0.31(0.01)$ & $0.29(0.01)$ & $0.54(0.14)$ & $0.28(0.01)$ & $0.31(0.01)$ & $0.30(0.01)$ & $0.32(0.05)$ & $0.28(0.03)$ \\
\hline Avail. P (mg kg-1) & $7.22(2.82)$ & $9.90(0.97)$ & $18.84(3.42)$ & 14.91(3.97) & $6.49(1.46)$ & $6.33(1.28)$ & $14.74(3.76)$ & $9.01(1.96)$ \\
\hline CEC $\left(\mathrm{cmol}_{\mathrm{c}} \mathrm{kg}^{-1}\right)$ & $15.60(2.22)$ & $11.51(1.26)$ & $12.00(2.53)$ & $9.31(1.21)$ & $9.78(1.14)$ & $7.08(0.51)$ & $10.00(1.10)$ & $8.05(0.96)$ \\
\hline Exch. K $\left(\mathrm{cmol}_{\mathrm{c}} \mathrm{kg}^{-1}\right)$ & $0.13(0.02)$ & $0.15(0.03)$ & $0.11(0.01)$ & $0.11(0.01)$ & $0.03(0.01)$ & $0.08(0.01)$ & $0.07(0.01)$ & $0.11(0.01)$ \\
\hline Exch. $\mathrm{Mg}\left(\mathrm{cmol}_{\mathrm{c}} \mathrm{kg}^{-1}\right)$ & $0.02(0.00)$ & $0.06(0.00)$ & $0.01(0.01)$ & $0.01(0.00)$ & $0.01(0.00)$ & $0.01(0.00)$ & $0.01(0.01)$ & $0.01(0.00)$ \\
\hline $\operatorname{Exch~Ca}\left(\mathrm{cmol}_{\mathrm{c}} \mathrm{kg}^{-1}\right)$ & $0.09(0.01)$ & $0.09(0.02)$ & $0.10(0.01)$ & $0.11(0.02)$ & $0.04(0.00)$ & $0.08(0.02)$ & $0.08(0.01)$ & $0.10(0.01)$ \\
\hline Exch $\mathrm{Al}\left(\mathrm{cmol}_{\mathrm{c}} \mathrm{kg}^{-1}\right)$ & $0.08(0.01)$ & $0.06(0.03)$ & $0.08(0.02)$ & $0.05(0.02)$ & $0.06(0.01)$ & $0.03(0.01)$ & $0.02(0.00)$ & $0.03(0.01)$ \\
\hline $\mathrm{MBC} / \mathrm{MBN}\left(\mathrm{mg} \mathrm{g}^{-1}\right)$ & $1.91(0.41)$ & $1.03(0.45)$ & $6.35(1.38)$ & $16.79(9.72)$ & $2.48(0.48)$ & $1.84(0.49)$ & $6.39(2.46)$ & $37.84(22.36)$ \\
\hline $\begin{array}{l}\text { Enzymatic actity } \\
\left(\mu \mathrm{g} \mathrm{g}^{-1} \text { soil } 0.5 \mathrm{~h}^{-1}\right)\end{array}$ & $24.45(0.65)$ & $22.91(0.53)$ & $26.51(0.63)$ & $24.89(1.22)$ & $22.25(0.49)$ & 17.91(1.73) & $25.74(1.13)$ & $22.92(0.76)$ \\
\hline
\end{tabular}

$\mathrm{PF}(1)$, planted forest of Tapah hill; SF, secondary forest; NF, natural forest; $\mathrm{PF}(2)$, planted forest of Chikus; C/N Ratio, carbon to nitrogen ratio;

$\mathrm{EC}$, electrical conductivity; $\mathrm{CEC}$, cation exchange capacity; $\mathrm{MBC}$, microbial biomass carbon; MBN, microbial biomass nitrogen

Table 3. Errors between Equations (5) and (6)

\begin{tabular}{lll} 
& Testing \\
\hline R1 & Actual & $-0.197 \mathrm{a}$ \\
R2 & $-0.063 \mathrm{a}$ & $-0.025 \mathrm{a}$ \\
R3 & $0.156 \mathrm{a}$ & $-0.190 \mathrm{a}$ \\
R4 & $0.177 \mathrm{a}$ & $-0.016 \mathrm{a}$ \\
R5 & $-0.123 \mathrm{a}$ & $0.191 \mathrm{a}$ \\
R6 & $0.278 \mathrm{a}$ & $0.513 \mathrm{a}$ \\
R7 & $-0.045 \mathrm{a}$ & $0.023 \mathrm{a}$ \\
R8 & $0.028 \mathrm{a}$ & $1.663 \mathrm{a}$ \\
R9 & $0.013 \mathrm{a}$ \\
R10 & $0.200 \mathrm{a}$ \\
R11 & $-0.075 \mathrm{a}$ \\
R12 & $0.107 \mathrm{a}$ \\
R13 & $0.052 \mathrm{a}$ \\
R14 & $0027 \mathrm{a}$ \\
R15 & $-0.027 \mathrm{a}$ \\
R16 & $-0.106 \mathrm{a}$ & $0.000 \mathrm{a}$ \\
\hline
\end{tabular}

Note: R, replicate; Different letters indicate significant differences between means of actual and testing data using a student's $t$-test ( $\mathrm{p}<0.05)$ 
Daljit Singh Karam et al. / American Journal of Applied Sciences 2017, 14 (1): 13.24 DOI: 10.3844/ajassp.2017.13.24

Table 4. $t$ - Test- Two-sample assuming equal variances

\begin{tabular}{lll}
\hline & Variable 1 & Variable 2 \\
\hline Mean & 0.04023876 & 0.122592075 \\
Variance & 0.013556736 & 0.193476707 \\
Observations & 16 & 16 \\
Pooled variance & 0.103516722 & \\
Hypothesized mean difference & 0 & \\
df & 30 & \\
$t$ Stat & -0.723970417 & \\
P $($ T-c- $t$ ) one-tail & 0.237346026 & \\
$t$ Critical one-tail & 1.697260851 & \\
P (T-C- $t$ ) two-tail & 0.474692051 & \\
$t$ Critical two-tail & 2.042272449 & \\
\hline
\end{tabular}

Table 5. Tropical soil quality index 2 results

\begin{tabular}{|c|c|c|c|c|c|}
\hline & & \multicolumn{2}{|l|}{$0.15 \mathrm{~cm}$} & \multicolumn{2}{|l|}{$15.30 \mathrm{~cm}$} \\
\hline & & Before & After & Before & After \\
\hline \multirow[t]{2}{*}{ Tapah Hill } & Planted forest & $59.23 \pm 4.81$ & $59.30 \pm 4.84$ & $49.83 \pm 1.90$ & $50.22 \pm 1.88$ \\
\hline & Secondary forest & $54.12 \pm 1.44$ & $54.17 \pm 1.41$ & $42.31 \pm 2.45$ & $42.23 \pm 2.52$ \\
\hline \multirow[t]{2}{*}{ Chikus } & Natural forest & $73.95 \pm 5.13$ & $73.90 \pm 5.41$ & $67.26 \pm 6.19$ & $67.13 \pm 6.27$ \\
\hline & Planted forest & $76.35 \pm 12.39$ & $76.71 \pm 12.65$ & $87.96 \pm 21.81$ & $94.92 \pm 24.25$ \\
\hline
\end{tabular}

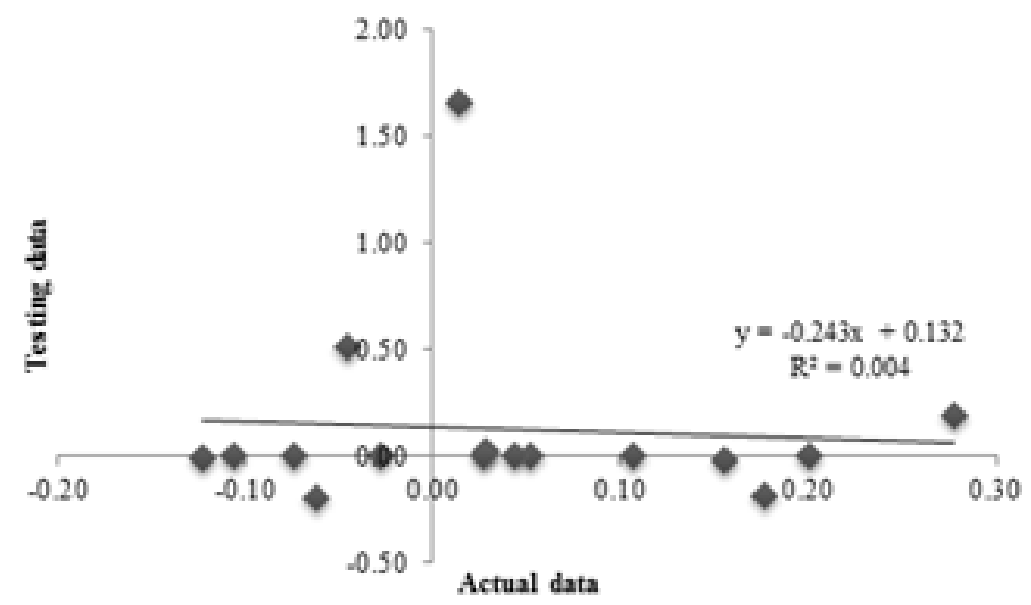

Fig. 1. Distribution of actual and testing data error of TSQI2

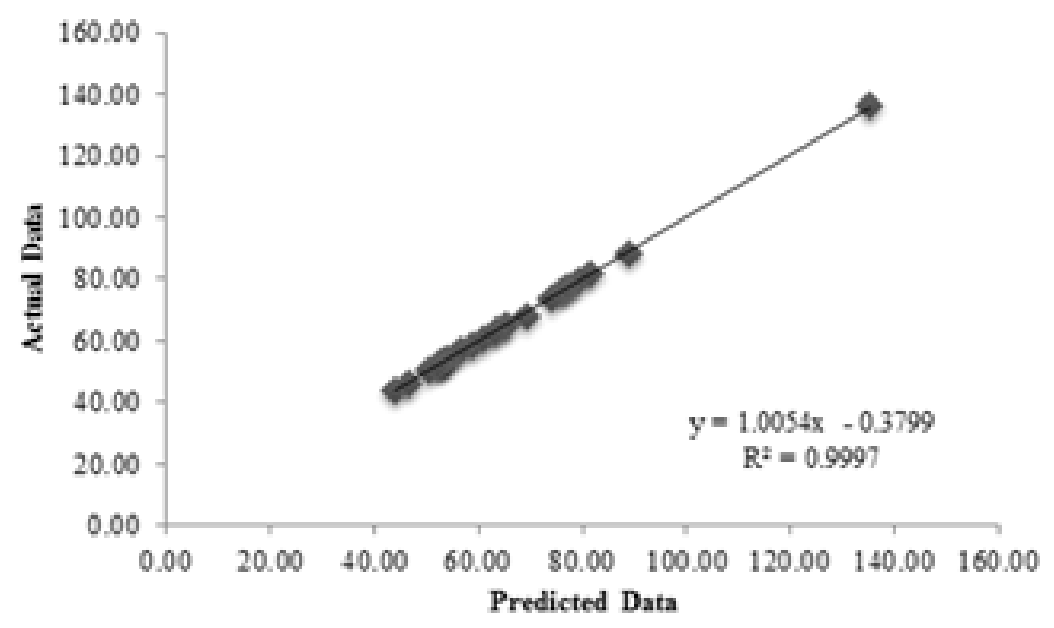

Fig. 2. Distribution of actual and predicted value of TSQI2 


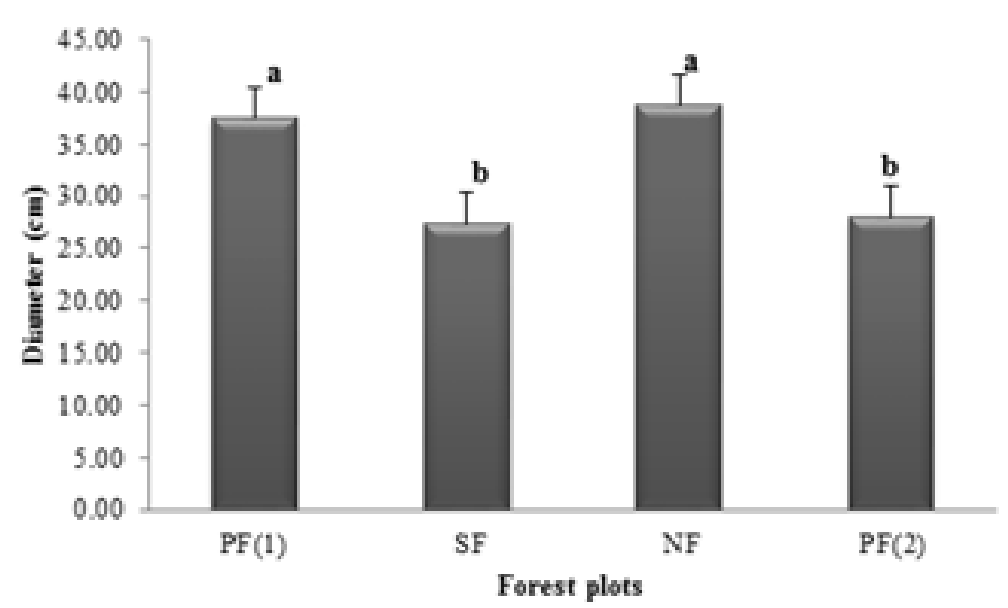

Fig. 3. Diameter of S. leprosula at each plot of Tapah Hill and Chikus Forest Reserve [(Note: PF(1), rehabilitated forest (Tapah Hill); $\mathrm{SF}$, secondary forest; NF, natural forest; $\mathrm{PF}(2)$, planted forest (Chikus)]

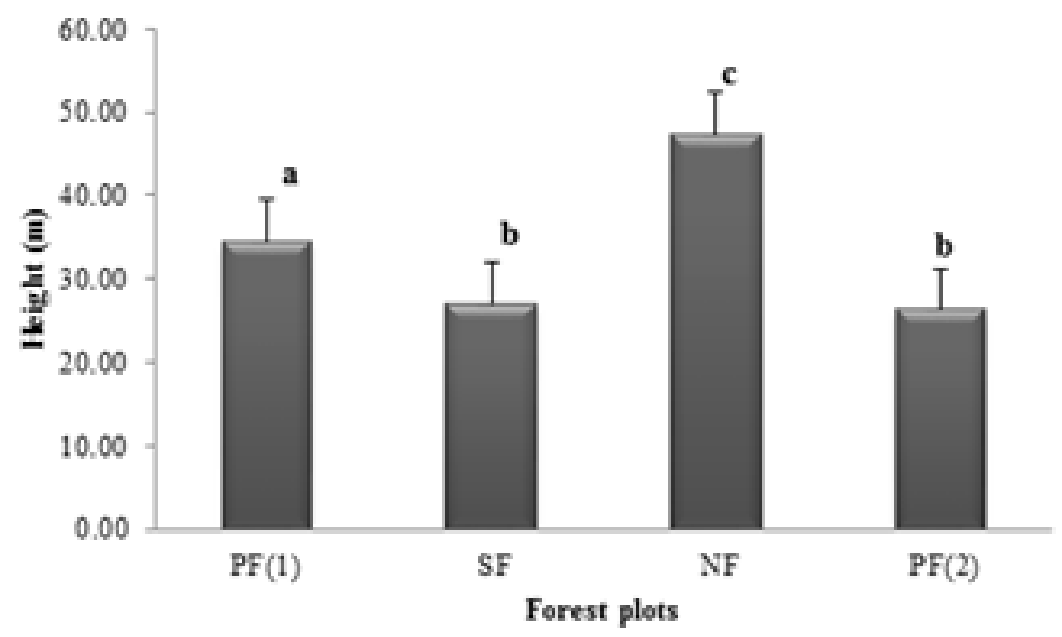

Fig. 4.Height of S. leprosula at each plot of Tapah Hill and Chikus Forest Reserve [(Note: PF(1), rehabilitated forest (Tapah Hill); SF, secondary forest; NF, natural forest; PF(2), planted forest (Chikus)]

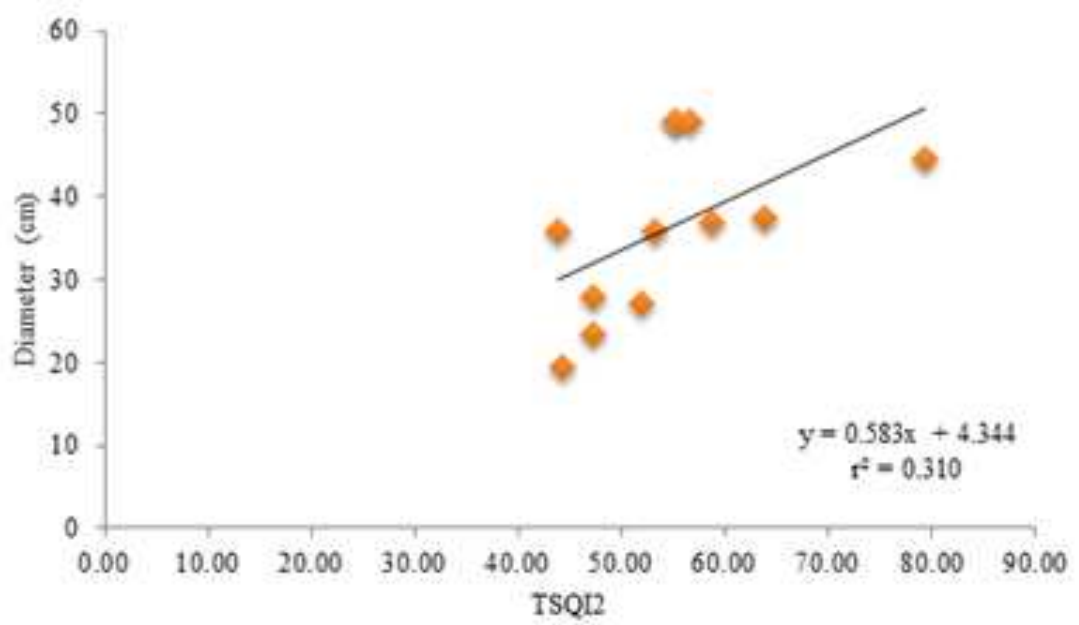

Fig. 5. Relationship between TSQI2 and tree diameter of planted forest in Tapah Hill Forest Reserve 


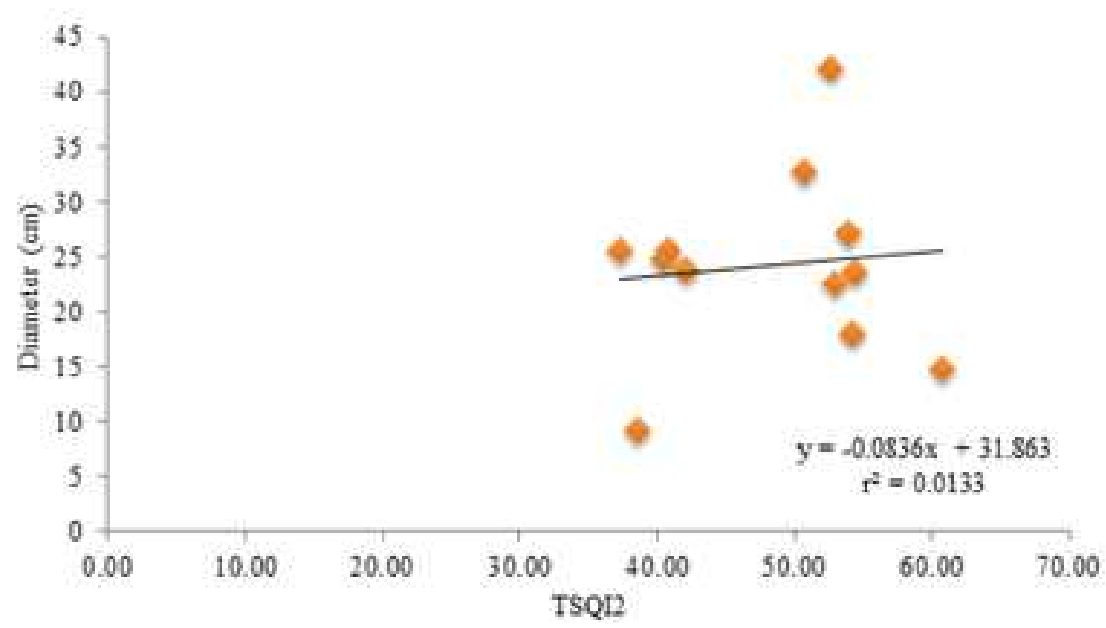

Fig. 6. Relationship between TSQI2 and tree diameter of secondary forest in Tapah hill forest reserve

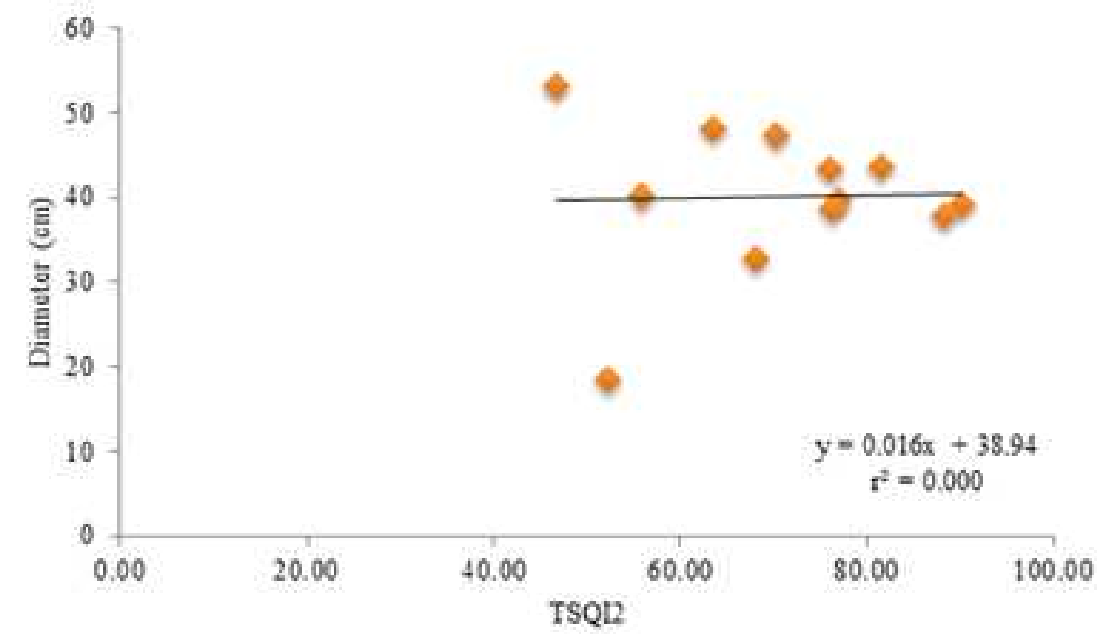

Fig. 7. Relationship between TSQI2 and tree diameter of natural forest in Chikus Forest Reserve

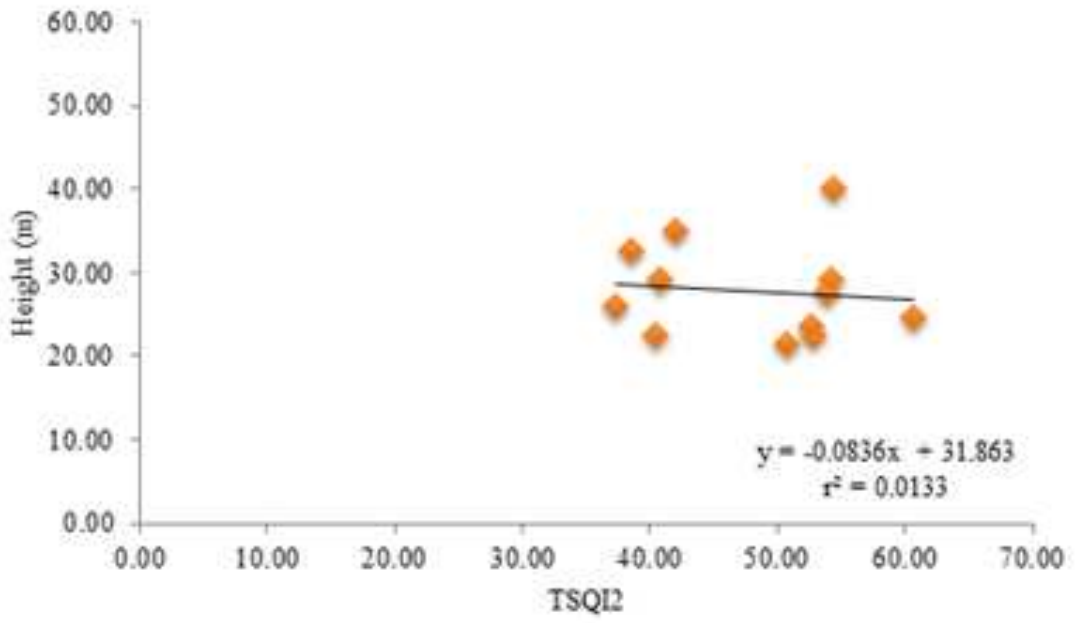

Fig. 8. Relationship between TSQI2 and tree diameter of planted forest in Chikus Forest Reserve 


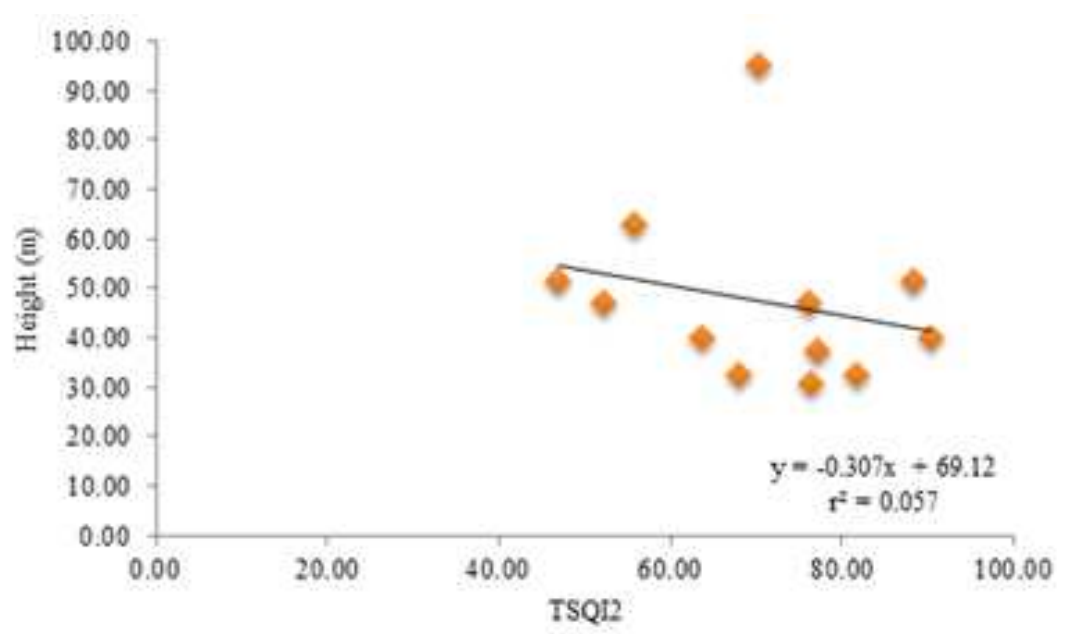

Fig. 9. Relationship between TSQI2 and tree height of secondary forest in Tapah Hill Forest Reserve

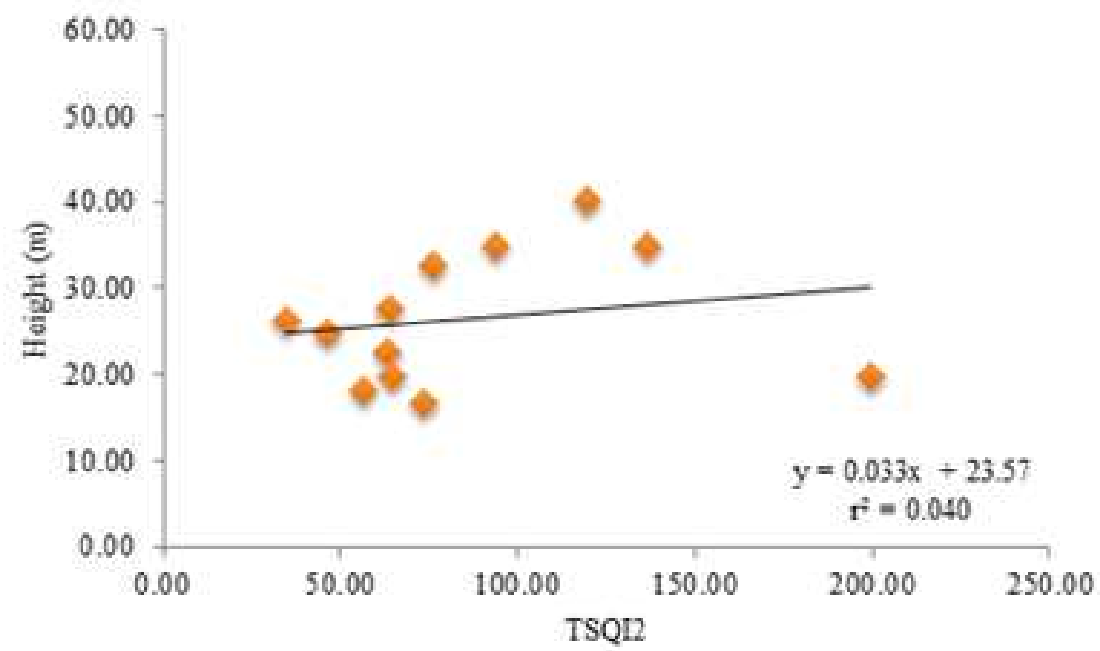

Fig. 10. Relationship between TSQI2 and tree height of natural forest in Chikus Forest Reserve

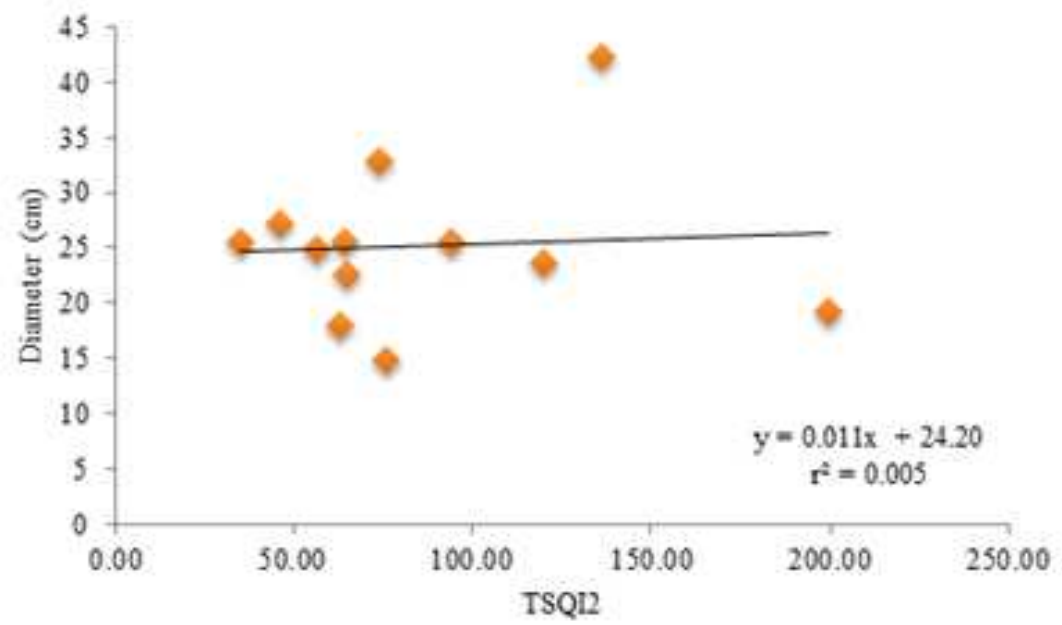

Fig. 11. Relationship between TSQI2 and tree height of planted forest in Chikus Forest Reserve 


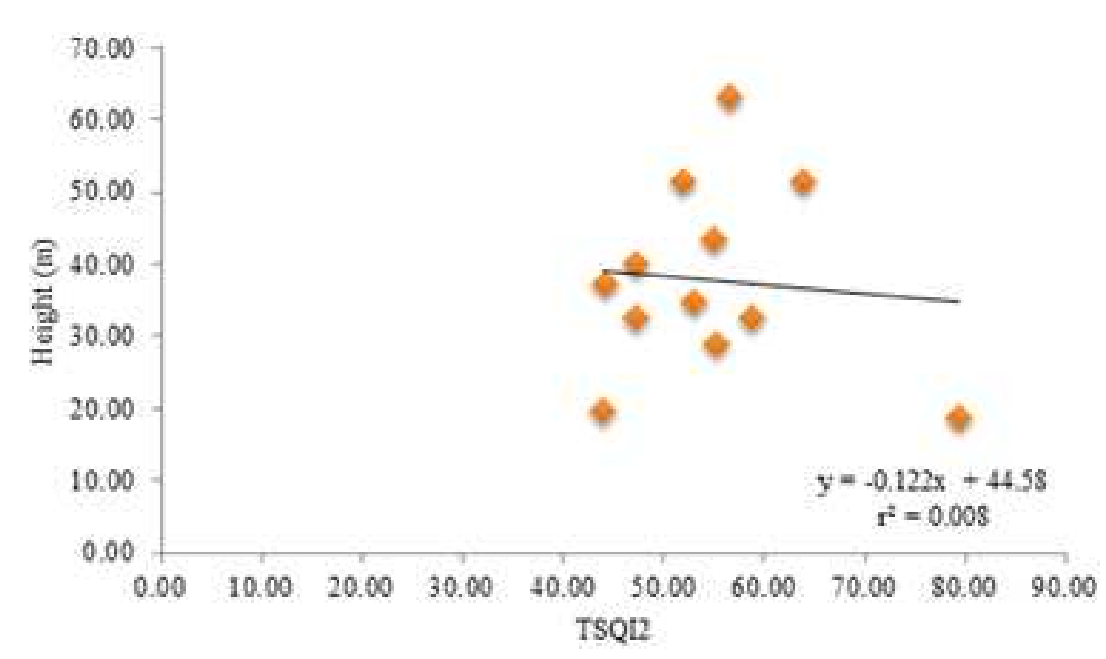

Fig. 12. Relationship between TSQI2 and tree height of planted forest in Chikus Forest Reserve

Figure 2 shows that the distributions of actual and predicted value of TSQI2 were increasing positively. The trends of the distribution prove that the TSQI2 is valid to be utilized for determination or measurement of soil quality for tropical forests.

Table 5 shows the results of applying this index at each site. The results are better for the rehabilitated forest of Chikus Forest Reserve compared to those of the rehabilitated forest of Tapah Hill Forest Reserve. Rehabilitated forest of Tapah Hill Forest Reserve had slightly higher index value compared to secondary forest. In contrast, planted forest of Chikus Forest Reserve had higher index value compared to natural forest which might be caused by higher $\mathrm{MBC} / \mathrm{MBN}$ ratio values. The reason for this condition could be due to lower amount of microbial biomass nitrogen as compared to microbial biomass carbon. However, in terms of suitability to be used for evaluating soil at different sites this index is valid for evaluation of soil quality.

Figure 3 and 4 show the tree diameter and height of S. leprosula at each forest plot. As for diameter at breast height, natural forest $(38.64 \pm 1.41 \mathrm{~cm})$ and rehabilitated forest $(37.48 \pm 1.59 \mathrm{~cm})$ and rehabilitated forest $(28.06 \pm 1.47 \mathrm{~cm})$ of Chikus Forest exhibited no comparative differences. Results showed that there were significant differences between $S$. leprosula heights between each plot. Natural forest $(47.41 \pm 3.30 \mathrm{~m})$ at Chikus Forest Reserves has the highest tree height, followed by rehabilitated forest in Tapah Hill (34.65 \pm 2.12 $\mathrm{m})$. Secondary forest $(27.08 \pm 1.71 \mathrm{~m})$ and another rehabilitated forest of $S$. leprosula $(26.42 \pm 1.79 \mathrm{~m})$ in Chikus Forest Reserve showed no significant differences.

There were no significant differences detected between TSQI1 and TSQI2 in terms of diameter and tree height for each plot (Fig. 5-12).

\section{Soil Quality Status based on Proposed TSQI}

Karlen et al. (2001; Lee et al., 2006) stated that soil quality illustrates the relationship and integration of physical, chemical and biological properties between soil constituents. The soil quality index provides a useful tool to those in or land usage management such as those responsible for forest rehabilitation programs, to examine the physical, chemical and biological properties of soil that change according to forest management practices (Masto et al., 2007; Zornoza et al., 2007). Many soil quality indices have been published or proposed, yet there is still no concrete index for evaluating soils around the world due to the variability and diversity of soils (Glover et al., 2000; Borken and Beese, 2002).

As for TSQI2, indice results favour the planted forest of Chikus Forest Reserve compared to the planted forest of Tapah Hill Forest Reserve. The planted forest of Tapah Hill Forest Reserve had a slightly higher index value compared to secondary forest. In contrast, the planted forest of Chikus Forest Reserve possessed higher index value compared to natural forest which might be caused by higher $\mathrm{MBC} / \mathrm{MBN}$ ratio values. This condition could be catalysed by the low amount of microbial biomass $\mathrm{N}$ as compared to microbial biomass C. However, in terms of suitability to be used to evaluate soil at different sites other than study plots, this index is valid for the evaluation of soil quality.

\section{Conclusion}

Tropical Soil Quality Index 2 (TSQI2), which was developed from multiple linear regression analysis and the index is valid, plus its incorporates all three soil properties which are bulk density, $\mathrm{pH}_{\mathrm{w}}$, electrical conductivity, $\mathrm{C} / \mathrm{N}$ ratio, cation exchange capacity, 
exchangeable potassium, available phosphorus, MBC/MBN ratio and microbial enzymatic activity. Further study in finding the permissible limits for this newly proposed index need to be carried out so that individual or bodies involves in soil quality measurements can quantify the current condition of particular forest soils.

\section{Acknowledgement}

The authors gratefully acknowledge Muveness Dorai for her editorial works. We acknowledge the financial support by Fundamental Research Grant Scheme (FRGS) from the Ministry of Higher Education of Malaysia (MOHE) through the Universiti Putra Malaysia (UPM), Malaysia.

\section{Author's Contribution}

Daljit Singh Karam: Involved in literature reviewing, sampling, laboratory analyses, data analyses and manuscript writing.

Arifin Abdu: Involved in data analyses and editing of the manuscript.

Keeren Sundara Rajoo: Involved in literature reviewing, sampling, laboratory analyses, data analyses and English editing work for the manuscript.

Mohamad Roslan Mohamad Kasim: Involved in data analyses and formation of soil quality index.

Farrah Melissa Muharam: Involved in statistical data analyses.

Hazandy Abdul Hamid: Involved in literature reviewing and editing of the manuscript.

\section{Ethics}

The corresponding author has confirms that all of the authors have read, reviewed and approved the manuscript for publication and no ethical issues involved.

\section{References}

Abdu, A., N. Aderis, H. Abdul-Hamid, N.M. Majid and S. Jusop et al., 2011. Using Orthosiphonstamineus B. for phytoremediation of heavy metals in soils amended with sewage sludge. Am. J. Applied Sci., 8: 323-331. DOI: 10.3844/ajassp.2011.323.331

Ahmadpour, P., A.M. Nawi, A. Abdu, H. Abdul-Hamid and D.K. Singh et al., 2010. Uptake of heavy metals by Jatrophacurcas L. planted in soils containing sewage sludge. Am. J. Applied Sci., 7: 1291-1299. DOI: 10.3844/ajassp.2010.1291.1299

Amacher, M.C., K.P. O’Neill and C.H. Perry, 2007. Soil vital signs: A news Soil Quality Index (SQI) for assessing forest soil health. Res. Pap. RMRS-RP65WWW. Fort Collins, CO: U.S. Department of Agriculture, Forest Service, Rocky Mountain Research Station, pp: 12.
Anderson, T.H., 2003. Microbial eco-physiological indicators to asses soil quality. Agric. Ecosyst. Environ., 98: 285-293. DOI: $10.1016 / \mathrm{S} 0167-8809(03) 00088-4$

Arifin, A., D.S. Karam, J. Shamshuddin, N.M. Majid and O. Radziah et al., 2012. Proposing a suitable soil quality index for natural, secondary and rehabilitated tropical forests in Malaysia. Afr. J. Biotechnol., 11: 3297-3309. DOI: $10.5897 / A J B 11.2903$

Bastida, F., A. Zsolnay, T. Hernández and C. Garcia, 2008. Past, present and future of soil quality indices: A biological perspective. Geoderma, 147: 159-171. DOI: 10.1016/J.GEODERMA.2008.08.007

Borken, W. and A.M.F. Beese, 2002. Changes in microbial and soil properties following compost treatment of degraded temperate forest soils. Soil Biol. Biochem., 34: 403-412.

DOI: 10.1016/S0038-0717(01)00201-2

Brookes, P.C., A. Landman, G. Pruden and D.S. Jenkinson, 1985. Chloroform fumigation and the release of soil nitrogen: A rapid direct extraction method to measure microbial biomass nitrogen in soil. Soil Biol. Biochem., 17: 837-842.

DOI: 10.1016/0038-0717(85)90144-0

Calster, H.V., L. Baeten, A.D. Schrijver, L.D. Keersmaeker and J.E. Rogister et al., 2007. Management driven changes (1967-2005) in soil acidity and the understorey plant community following conversion of a coppice-with-standards forest. Forest Ecol. Manage., 241: 258-271.

DOI: 10.1016/J.FORECO.2007.01.007

Dawson, J.J.C., E.J. Godsiffe, I.P. Thompson, T.K. Ralebitso-Senior and K.S. Killham et al., 2007. Application of biological indicators to assess recovery of hydrocarbon impacted soils. Soil Biol. Biochem., 39: 164-177. DOI: $10.1016 /$ J.SOILBIO.2006.06.020

Doran, J.W., 2002. Soil health and global sustainability: Translating science into practice. Agric. Ecosyst. Environ., 88: 119-127. DOI: $10.1016 / \mathrm{S} 0167-8809(01) 00246-8$

Franzluebbers, A.J., 2002. Soil organic matter stratification ratio as an indicator of soil quality. Soil Tillage Res., 66: 95-106. DOI: $10.1016 / \mathrm{S} 0167-1987(02) 00018-1$

Gagnon, V., F. Chazarenc, Y. Comeau and J. Brisson, 2007. Influence of macrophyte species on microbial density and activity in constructed wetlands. Water Sci. Technol., 56: 249-254. DOI: $10.2166 /$ wst.2007.510

Glover, J.D., J.P. Reganold and P.K. Andrews, 2000. Systematic method for rating soil quality of conventional, organic and integrated apple orchards in Washington State. Agric. Ecosyst. Environ., 80: 29-45. DOI: 10.1016/S0167-8809(00)00131-6 
Gupta, P.K., 2007. Soil, Plant, Water and Plant Analysis. 2nd Edn., Agribios, India.

Herrick, J.E., 2000. Soil quality: An indicator of sustainable land management? Applied Soil Ecol., 15: 75-83. DOI: 10.1016/S0929-1393(00)00073-1

Karam, D.S., A. Abdu, R. Othman, S. Jusop and A.H.M. Hanif, 2014. Impact of enrichment planting activity on soil physico-chemical properties of degraded forestland. Int. J. Environ. Sci., 5: 407-422. DOI: 10.6088/ijes.2014050100035

Karam, D.S., A. Abdu, O. Radziah, J. Shamshuddin and M.H.A. Husni et al., 2013a. Changes in the physicochemical properties of soils under rehabilitated lowland dipterocarps forest at Chikus Forest Reserve, Perak, Malaysia. J. Macro Trends Applied Sci., 1: 42-57.

Karam, D.S., A. Abdu, O. Radziah, J. Shamshuddin and H. Abdul-Hamid et al., 2011. Assessing soil biological properties of natural and planted forests in the Malaysian tropical lowland dipterocarp forest. Am. J. Applied Sci., 8: 854-859.

DOI: 10.3844 /ajassp.2011.854.859

Karam, D.S., A. Arifin, O. Radziah, J. Shamshuddin and H. Abdul-Hamid et al., 2013b. Evaluation of soil biological properties of 9-and 15- year-old stands in the oil palm plantation in Perak, Malaysia. Afr. J. Agric. Res., 8: 3904-3910. DOI: $10.5897 / A J A R 11.772$

Karam, D.S., A. Arifin, O. Radziah, J. Shamshuddin and N.M. Majid et al., 2012. Impact of long-term forest enrichment planting on the biological status of soil in a deforested dipterocarp forest in perak, Malaysia. Sci. World J. DOI: 10.1100/2012/641346

Karam, D.S., M.N.C. Jamil, N. Jaafar, K.S. Rajoo and A. Arifin, 2015. Effects of different incubation periods on Microbial Biomass Carbon (MBC) in two soil series. J. Environ. Sci. Pollut. Res., 1: 20-22.

Karlen, D.L., S.S. Andrews and J.W. Doran, 2001. Soil quality: Current concepts and applications. Adv. Agronomy, 74: 1-40.

DOI: $10.1016 / \mathrm{S} 0065-2113(01) 74029-1$

Lee, C.H., M.Y. Wu, V.B. Asia and C. Zueng-Sang, 2006. Using a soil quality index to assess the effects of applying swine manure compost on soil quality under a crop rotation system in Taiwan. Soil Sci., 171: 210-222.

DOI: $10.1097 / 01 . s s .0000199700 .78956 .8 \mathrm{c}$

Malik, M.N.A., A. Abdu, D.S. Karam, S. Jusop and H.A. Hamid et al., 2015. The fertility status of soils at rehabilitated degraded land in Universiti Putra Malaysia planted with Pinuscaribaea and Swietenia macrophylla. Am. J. Applied Sci., 12: 752-758. DOI: 10.3844/ajassp.2015.752.758
Masto, R.E., P.K. Chhonkar, D. Singh and A.K. Patra, 2007. Soil quality response to long-term nutrient and crop management on a semi-arid Inceptisol. Agric. Ecosyst. Environ., 118: 130-142.

DOI: 10.1016/J.AGEE.2006.05.008

Mohd-Aizat, A., M.K. Mohamad-Roslan, W.N.A. Sulaiman and D.S. Karam, 2014. The relationship between soil $\mathrm{pH}$ and selected soil properties of degraded forestland. Int. J. Environ. Sci., 5: 407-422.

Pang, X.Y., W.K. Bao and Y.M. Zhang, 2006. Evaluation of soil fertility under different Cupressus chengiana forests using multivariate approach. Pedosphere, 16: 602-615. DOI: 10.1016/S1002-0160(06)60094-5

Puglisi, E., A.A.M. Del Re, M.A. Rao and L. Gianfreda, 2006. Development and validation of numerical indexes integrating enzyme activities of soils. Soil Biol. Biochem., 38: 1673-1681.

DOI: 10.1016/J.SOILBIO.2005.11.021

Rajoo, K.S., A. Abdu, H. Abdul-Hamid, S. Jusop and W.W. Zhen, 2013a. Heavy metal uptake and translocation by Dipterocarpus verrucosus from sewage sludge contaminated soil. Am. J. Environ. Sci., 9: 259-268. DOI: 10.3844/ajessp.2013.259.268

Rajoo, K.S., A. Abdu, H. Abdul-Hamid, D.S. Karam and S. Jusop et al., 2013b. Assessment of heavy metals uptake and translocation by Aquilaria malaccensis planted in soils containing sewage sludge. Am. J. Applied $\quad$ Sci., $\quad 10$ : 952-964. DOI: 10.3844/ajassp.2013.952.964

Rajoo, K.S., D.S. Karam, A. Arifin and F.M. Muharam, 2016a. Phytoremediation potential of Dipterocarpus chataceus planted on sewage sludge contaminated soil. Middle-East J. Sci. Res., 24: 1169-1177.

Rajoo, K.S., A. Ismail, D.S. Karam and F.M. Muharam, 2016b. Phytoremediation studies on soils contaminated with heavy metals in Malaysia: A Review Article. American-Eurasian J. Agric. Environ. Sci., 16: 1504-1514.

DOI: 10.5829/idosi.aejaes.2016.1504.1514

Sánchez-Monedero, M.A., C. Mondini, M.L. Cayuela, A. Roig and M. Contin et al., 2008. Fluorescein diacetate hydrolysis, respiration and microbial biomass in freshly amended soils. Biol. Fertility Soils, 44: 885-890. DOI: 10.1007/s00374-007-0263-1

Schloter, M., O. Dilly and J.C. Munch, 2003. Indicators for evaluating soil quality. Agric. Ecosyst. Environ., 98: 255-262. DOI: 10.1016/S0167-8809(03)00085-9

Singh, K.S.D., A. Arifin, O. Radziah, J. Shamshuddin and A.H. Hazandy et al., 2013. Status of soil microbial population, enzymatic activity and biomass of selected natural, secondary and rehabilitated forests. Am. J. Environ. Sci., 9: 301-309.

DOI: 10.3844/ajessp.2013.301.309 
Vásquez-Murrieta, M.S., B. Goaverts and L. Dendooven, 2007. Microbial biomass $\mathrm{C}$ measurements in soil of the central highlands of Mexico. Applied Soil Ecol., 35: 432-440. DOI: 10.1016/J.APSOIL.2006.06.005

Witt, C., J.L. Gaunt, C.C. Galicia, J.C.G. Ottow and H.U. Neue, 2000. A rapid chloroform-fumigation extraction method for measuring soil microbial biomass carbon and nitrogen in flooded rice soils. Biol. Fertility Soils, 30: 510-519.

DOI: $10.1007 / \mathrm{s} 003740050030$
Zornoza, R., J. Mataix-Solera, C. Guerrero, V. Arcenegui and F. García-Orenes et al., 2007. Evaluation of soil quality using multiple lineal regression based on physical, chemical and biochemical properties. Sci. Total Environ., 378: 233-237. PMID: 17321568 